\title{
An Imagined Community of Their Own: Voices of Italian Immigrants in IL LAVORATORE ItALIANO
}

\section{Thierry Rinaldetti}

Abstract: This contribution proposes to reflect on the experience and sense of identity of Italians through the analysis of Il Lavoratore Italiano, an Italian-language radical weekly newspaper published in Kansas from 1905 to 1927. A mouthpiece for Italian rank-andfile radicals in the U.S., the periodical opened its pages to readers established in mining communities throughout the Midwest, the Mountain States, and the Southwest. Based on the analysis of all issues of the newspaper dated 15 December 1905 to 24 August 1906, this essay examines the interactions at work within and around $I l$ Lavoratore Italiano between the newspaper's editors and its readers, with editors of different publications and radicals of different persuasions, and between readers. The author stresses the overall importance of exchanges among readers themselves, as well as the role these exchanges at the bottom end of the editorial process actually played in shaping early communities of Italian immigrants who still largely defined themselves in local terms, in spite of their radical sympathies and the editors' agenda. With their personal networks of relatives and friends dispersed in a significant number of mining towns across the U.S., Italian labour migrants would commonly use the newspaper's pages to keep in touch with faraway communities and share the information they needed to circulate among them. To these "Italian workers of the world", Il Lavoratore Italiano proved to be a very efficient means to reinforce their networks and reduce, in the process, the distances between mining communities.

Since the discovery of the dynamic and interactional character of ethnicity, sources internal to the ethnic groups themselves—as opposed to mainstream sources - have often been studied in order to hear the voices of the individuals whose characteristics and feelings are under scrutiny. The study of the immigrant press in particular has increased our understanding of early Italian immigration 
in the United States. However, case studies of the Italian immigrant press have focused mainly on the lives and ideologies of newspaper founders and editors or on the press treatment of specific topics. Research interest spans the leadership role of newspaper directors within their ethnic community and beyond (Deschamps and Luconi) and the positions of Italian-language titles on a number of issues such as the acquisition of U.S. citizenship by Italian immigrants (Deschamps, "L'épreuve"), the values of their host society (Luconi), the position of the U.S. in WWI (Nelli), and the glorification and diffusion of Italian cultural heritage (Deschamps, "La scoperta dell'America"). However, the voices of average readers and contributors themselves generally have received less attention.

This contribution proposes to reflect on the experience and sense of identity of Italians through the analysis of Il Lavoratore Italiano, a radical weekly newspaper published in Italian in Pittsburg, Kansas, from 1905 to 1927. In opening its pages to readers established in mining communities throughout the Midwest, the Mountain States, and the Southwest, Il Lavoratore Italiano, which was the organ of the Western Federation of Miners (WFM) for a while, served as a mouthpiece for Italian rank-and-file radicals in the United States. All issues of the newspaper dated 15 December 1905 to 24 August 1906 have been scrutinized with a view to understanding how the newspaper's diverse, distant, and sometimes discordant voices both reflected and shaped a specific collective identity. ${ }^{1}$ This rather short time period, which corresponds to eight months of weekly publications of Il Lavoratore Italiano, allowed for a detailed analysis of the distinct interactions at work within, and around, the newspaper: between its editors and fellow editors of other radical titles; between the editors and their readers; and between readers themselves.

Like most of their peers in the early Italian-language radical press, the editors of Il Lavoratore Italiano struggled to articulate two agendas that were not always easy to reconcile: the diffusion of the principles of working-class solidarity on the one hand, and the mobilization of Italian workers of diverse regional origins on the basis of their Italianness on the other. However, the editors' dream of an ideal community of Italian workers devoted to revolutionary industrial unionism proved short-lived, for it was largely discredited by the ceaseless in-fighting between radicals; this took place not only among contributors to Il Lavoratore Italiano but also among the editors of L'Unione, another radical title competing for the

\footnotetext{
${ }^{1}$ In addition, the author has read many later issues of the newspaper.
} 
loyalty of Italian workers in the mining communities of the western United States. Additionally, the editors' imagined community did not always appeal to workers whose sense of interethnic solidarity and of Italianness found its limits in their daily lives and experiences in the field. However, from the readers' vantage point, Il Lavoratore Italiano provided a much-needed forum of discussion where they could voice their grievances, keep in touch with relatives and friends established in other mining communities, and, above all, exchange whatever information those "workers of the world" needed in order to circulate as they did between mining areas across the U.S. and even beyond.

\section{From the top down: propaganda and education in Il Lavoratore Italiano, or the editors' ideal community}

Il Lavoratore Italiano was first published in Kansas in 1905 by Edoardo Caffaro, an Italian immigrant from Turin, Piedmont, who came to Pittsburg after having already spent several years in the small mining town of Trinidad, Colorado, and whose views were inspired by socialist as well as syndicalist ideas. Il Lavoratore Italiano rapidly joined the ranks of the WFM, a union that played a crucial part in the founding in June 1905 of the powerful and revolutionary Industrial Workers of the World (IWW) and provided it with a significant number of activists and several of its officials, including Bill Haywood, one of its most prominent figures. Il Lavoratore Italiano, which had initially presented itself as "The Weekly Newspaper of the United Italian Workers of America," clearly announced as early as April 1906 that it was "Devoted to the interest of the Western Federation of Miners and Industrial Unionism.". As the official organ of the WFM, Il Lavoratore Italiano regularly published information on the activities of the union's different localsmainly, though not exclusively, those of the Western and Midwestern states.

Like most Italian-language publications produced by and for the immigrants themselves, Il Lavoratore Italiano also had an educational mission (Prencipe 516), which one of the newspaper's local contacts in Colorado promoted in the following terms:

Comrades! Take a subscription to 'Il Lavoratore Italiano', one of the rare newspapers that defend our cause and don't tell lies. This

\footnotetext{
2 This was printed in English in the newspaper. Il Lavoratore Italiano remained loyal to both the WFM and revolutionary industrial unionism even after the WFM left the IWW in 1907.
} 
is the paper that defends our interests, educates the unaware, and encourages the shy. Through its columns, we'll learn to love each other, and to become dignified people, aware of the righteousness of our struggle against exploitation.

Compagni! Abbonatevi a 'Il Lavoratore Italiano,' uno dei pochi giornali italo-americani che difendono la nostra causa e non dicono bugie. Esso è l'organo difensore dei nostri interessi, l'educatore degli inconscienti, lo svegliatore degli ignari, l'incoraggiatore dei timidi. Dalle colonne di questo giornale noi impareremo ad amarci, divenire dignitosi, consapevoli del buon diritto che ci assiste nella battaglia che combattiamo contro lo sfruttamento. ${ }^{3}$

In addition to the newspaper's extensive coverage of union activities, the purpose of a significant number of articles was therefore to sensitize readers to issues such as the devastating effects of alcohol consumption; the insidious, pervasive influence of the Roman Catholic Church and its priests within communities of Italian immigrants; or the defence of women's rights. Appalling and, sadly, often true accounts of the life and lot of the miner were provided in a column aptly titled "How the Miners Live and Die" ("Come vivono e muoiono i minatori"), therefore ensuring that the seeds of revolt be sowed in any sensible mind. In other columns, such as "The Pink Column" ("Cronaca rosa") or "Priest Flesh" ("Carne di prete"), and sometimes through satirical cartoons as well, Il Lavoratore Italiano denounced religious bigotry among fellow Italian workers.

In the newspaper, a variety of Italian radical institutions—such as local miners' clubs, Socialist circles, and mutual benefit societies— placed ads, published their statutes and rules, as well as their lists of members appointed or elected to different offices. This not only provided Il Lavoratore Italiano with a much-needed source of revenue, but it also contributed to opening its pages — and the debateto a larger audience of radical activists and sympathizers of different persuasions. However, Il Lavoratore Italiano unambiguously sponsored revolutionary industrial unionism and the international solidarity of workers of all origins; the lack of any reference to black workers or blackness in general seems quite surprising, though, given the Italians' self-awareness of their racial otherness. Much of the newspaper

\footnotetext{
${ }^{3}$ Il Lavoratore Italiano, 2 Feb. 1906. All English translations are my own.
} 
was therefore devoted to revolutionary action in Europe, and announcements by non-Italian radical groups-French ones in particular-were also published (in Italian). Even after the WFM left the IWW in 1907, the newspaper's editorial line actually remained loyal both to the WFM and to the IWW's revolutionary ideals. Unsurprisingly, much of the editorial space and, in particular, a number of leading articles and columns signed by prominent Italian-American radicalssuch as WFM national organizer Giacomo Peretto and socialist leader Charles Demolli-were devoted to the promotion of class solidarity between workers of all nationalities.

At the same time, Il Lavoratore Italiano also launched frequent calls for the unity of Italian workers of different origins. This was not in contradiction with its internationalist agenda: in the early twentieth century, one of the major challenges of the Italian-American labour movement-and, for that matter, of the editors of Il Lavoratore Italiano - was to unite workers divided not only ideologically but also regionally (Bezza; Cannistraro and Meyer; Gabaccia and Ottanelli; Pernicone; Topp; Vezzosi, Il socialismo indifferente). Significantly, a contributor from the state of Washington complained about regionalism in an article entitled "Italians from the south, the north... and the center": "Very little is actually said or done about 'regionalism', a prejudice even worse than religious prejudice, even though the prejudice is deeply rooted in the minds of Italian workers, and it sometimes has regrettable consequences" ("Del 'regionalismo' che è un pregiudizio forse peggiore di quello religioso, ce ne occupiamo poco, quantunque esso abbia radici profonde nelle menti degli operai italiani e produca di tanto in tanto effetti deplorevoli"). ${ }^{4}$ In these conditions, the editors of Il Lavoratore Italiano probably considered that appealing to the readers' sense of Italianness was a means to an end, a mere step towards achieving their ultimate goal. Indeed, Bruno Cartosio convincingly argued that, "in doing his 'educational' work in his own way, within his own community, he [the immigrant activist] relied on the belief that others like himself were doing the same in their own communities and that eventually things would change for the better" (Cartosio, "Gli emigrati italiani," 431).

At a time when assimilationist hard-liners promoted "one-hundred-percent Americanism," as well as the associated figure of the loyal and productive immigrant, who learned English at night, forgot about his homeland, rapidly became a U.S. citizen, respected U.S. authorities, and did not strike (Lacorne 230), Il

\footnotetext{
4 “Meridionali, Settentionali e ... Centrali," Il Lavoratore Italiano, 2 Mar. 1906.
} 
Lavoratore Italiano was proposing a competing version of the good immigrant: that of a class-conscious worker of Italian origin, who was entirely committed to the cause of the revolution, did not drink, did not overemphasize his regional origin, took up the fight against religious bigotry in his own community, respected women and defended their rights, and made it a point of honour to educate himself in ideological and linguistic matters by taking out a subscription to Il Lavoratore Italiano. However, the idealized community of Italian radicals propounded by the editors of Il Lavoratore Italiano was not always easy to reconcile with his own experiences, both as a reader and as an immigrant worker, as the newspaper's columns frequently exposed the divisions and conflicts between radicals, and its editorial line did not always reflect the reader's most immediate concerns.

\section{Bones of contention among radicals, or the fall of the editors' ideal community, part 1}

Owing to its ideological stance and its position as the official organ of the WFM, Il Lavoratore Italiano almost immediately clashed with the more conservative United Mine Workers of America (UMWA), itself affiliated with the corporatist American Federation of Labor (AFL). The pages of Il Lavoratore Italiano soon became a battleground where the two unions competed ferociously, and at times viciously, for the loyalty of Italian workers settled in the mining camps of the Rockies and the Southwest, in Colorado, Arizona, Utah, New Mexico, Idaho, Wyoming, and Montana. The columns of Il Lavoratore Italiano were pervaded with full-fledged attacks on the UMWA, the AFL, and all those who had been found or were suspected to be their allies among the local politicians, establishment, and press.

A significant number of neologisms, set phrases, and disparaging terms were used in reference to the enemies and their allies. For example, the last name of James Hamilton Peabody, the infamous governor of Colorado who had sent for the National Guard, declared martial law, and had dozens of strikers deported in 1904 (Notarianni), was almost systematically used as an adjective- - "Peabodian"- to qualify the UMWA, which Il Lavoratore Italiano accused of being in collusion with the mining companies and the "capitalist class of the west." Similarly, the use of the adjective "Mitchellian," from the name of the president of the UMWA, John Mitchell, was generally sufficient to ensure that readers would

\footnotetext{
${ }^{5}$ Il Lavoratore Italiano, 9 Mar. 1906.
} 
understand perfectly the matter at hand and its implications without any explicit reference to the rival union. ${ }^{6}$

Such terms were applied also to other protagonists, such as the citizens' alliances, formed to defend the interests of the companies during the violent clashes that frequently erupted in mining camps of the west. Above all, these terms were almost systematically applied to the Unione, another radical Italianlanguage weekly newspaper (published in Pueblo, Colorado), which Il Lavoratore Italiano considered one of its worst enemies; this competing title, which claimed to be independent while at the same time being the official organ of an ItalianAmerican socialist organization (the Federazione Colombiana), was closer to the UMWA's more moderate brand of unionism. Here again, the mere mention of "Peabodian newspaper" (giornale peabodico) was enough to be understood by readers without having to name the competitor. ${ }^{7}$ Challenging the Unione on both the letter and the spirit, Il Lavoratore Italiano went so far as to create a column titled "The Howler Museum" ("Il museo delle asinerie"), in which the competitor's spelling or grammatical errors were ridiculed, as in the following extract from the 15 December 1905 issue:

Dear Madam Unione, let me tell you something, and let this be between you and me: 'inauguration', as I've said over and over again, takes only one ' $n$ '. What the hell! A descendant of Christopher Columbus, a leading figure of the Italian community, one who will have the name of Italy praised abroad, and who can't spell the language spoken in Italy! But perhaps my colleague hopes to honor and glorify the name of Italy by propagating illiteracy.

Signora Unione! Senta e che resti tra noi: 'inaugurazione,' lo dissi e lo ripeto si scrive con un $\mathrm{n}$ solo. Diavolo! Un discendente di Cristoforo Colombo, un prominente che vuol tenere alto il nome d'Italia all'estero e che non conosce l'ortografia della lingua che in Italia si parla! Crede forse la ineffabile consorella che l'unico modo

${ }^{6}$ Ibid., 15 Dec. 1905; 29 June 1906.

${ }^{7}$ Ibid., 15 Dec. 1905. 
di dare onore e lustre al nome italiano sia quello di far propaganda d'analfabetismo? ${ }^{8}$

The authors of such mistakes were deemed incompetent and therefore unworthy of representing Italian workers' interests. This was a most serious condemnation, given that, at the turn of the twentieth century, many Italians still spoke only their regional dialects and did not know much Italian, and one of the missions of the radical Italian-language press was, precisely, to unite workers of different regional origins around Italian language and culture. At the same time, one may wonder whether such negative comments about mistakes in orthography made $I l$ Lavoratore Italiano look bitter or simply petty.

In her study of the interactions between readers and editors in Ameryka-Echo, a major contemporary Polish-language newspaper, Anna Jaroszyńska-Kirchmann convincingly argued that, in promoting such values as democracy, freedom of expression, tolerance, respect, and self-improvement, the newspaper's editors successfully created a public sphere where a diversity of voices—ethnic, socio-economic, religious, and ideological—could be expressed and where individuals with potentially conflicting views within the Polish community would somehow learn to interact with each other (Jaroszyńska-Kirchmann). While claiming a similar objective of bringing together Italian workers divided regionally and ideologically, Il Lavoratore Italiano did not achieve anything even remotely comparable: the tone of the debate with editors of competing publications and, more generally, with radical leaders expressing diverging views sometimes took the form of violent verbal exchanges, which in turn influenced both the spirit and the letter of the contributions of rank-and-file activists and ordinary readers. In one such contribution, entitled "A true bastard" ("Una carogna autentica"), someone who was accused of being a socialist only in name and of belonging to the "Peabodian sect" (la setta peabodica) was compared to a "snake leaving traces of its passage behind it as it slithers off on a dirt road" ("un serpe che strisciando rapidamente sulla via polverosa lascia dietro di sè leggera traccia del suo corpo"). ${ }^{9}$ In another article, ending with "good riddance," someone who had claimed to be a Catholic in his own contribution was accused of having a "hypocrite's soul." ${ }^{10}$ Arguably, it

\footnotetext{
${ }^{8}$ Ibid., 22 Dec. 1905.

${ }^{9}$ Il Lavoratore Italiano, 15 Dec. 1905.

${ }^{10}$ Ibid., 26 Apr. 1906.
} 
was perhaps to prevent personal attacks of this type that readers sometimes wrote anonymous letters or signed somebody else's name. ${ }^{11}$

\section{From the bottom up: the voices of the readers, or the fall of the editors' ideal community, part 2}

Undoubtedly, the columns of Il Lavoratore Italiano exposed the reader to a somewhat disheartening reality made of insurmountable divisions and violent clashes between Italian union leaders and activists. However, they also exposed the reader to the sometimes-considerable gap between the paper's ideological stance and the reader's daily life and concerns. Elisabetta Vezzosi has shown how, in contributing to the creation of a sub-community with its own subculture, a major radical Italian-language publication like Il Proletario actually further reinforced the divisions within the Italian-American communities it addressed and claimed to represent-even if only partly (Vezzosi, "Class, Ethnicity, and Acculturation," 452 -453). Her conclusions are based on a thorough analysis of Il Proletario's editorial line during the WWI years, which she convincingly argued was at odds with the concerns and opinions of an increasingly large number of Italian immigrants in the U.S.- many of whom, it should be noted, would not have read Il Proletario regardless. The case of Il Lavoratore Italiano reveals that even a radical title whose readership was considerably smaller-and, arguably, less diverse-could fail to be in tune not only with the majority of non-readers but also with its own readers. By offering first-hand accounts of the readers' experiences, the letters and contributions published in Il Lavoratore Italiano provide some direct insight into the immigrants' most immediate concerns, which in turn allows perhaps for a more direct assessment of the actual gap between their concerns and the editors'.

As readers interacted directly with each other in the pages of Il Lavoratore Italiano, they sometimes spontaneously expressed their solidarity with perfect strangers. For instance, in answer to a testimony published three weeks earlier by a fellow Italian miner wishing to change mining camps because of the repression of radicals in Wyoming, ${ }^{12}$ a reader in Utah wrote: "If you intend to leave Wyoming, I'd be prepared to help you anytime so that you can escape from the grip of those disgusting individuals" ("Se avesse intenzione di abbandonare il Wyoming io sarei

\footnotetext{
${ }^{11}$ Ibid., 26 Apr. 1906; 25 May 1906.

12 Il Lavoratore Italiano, 19 Apr. 1906.
} 
disposto ad aiutarlo in qualunque momento per toglierlo di mezzo a quella gente schifosa"). ${ }^{13}$ However, such demonstrations of solidarity on the part of readers were not so common in Il Lavoratore Italiano, and certainly not as common as expressions of regional prejudice. For instance, in his description of the local Italian colony, a contributor in Pueblo, Colorado, could not help distancing himself from his compatriots from the south of Italy:

Almost all the Italian workers are from the south. After work, they attend religious services. Nothing else matters to them. These poor people bend and grow old prematurely under the pressure of hard work and religion. They don't even know that a better life could be possible in this world.

Gli operai italiani sono quasi tutti meridionali. Costoro finito la loro giornata ed assistito alle funzioni religiose... non si occupano d'altro. I poveretti invecchiano precocemente, curvati dalla fatica e non sanno nemmeno che a questo mondo si potrebbe vivere una vita più umana. ${ }^{14}$

Another contributor in Mc Guire, Colorado, blamed the murder of an old man at the hands of his own son not only on the perpetrator's drunkenness but also on the supposedly hotter temper of southern Italians: "Once again, the too ardent blood of our southern compatriots sadly manifested itself a few days ago" ("Il troppo ardente sangue dei nostri compatrioti meridionali dava giorni sono ancora triste prova di sè"). ${ }^{15}$

Appeals to the workers' sense of Italianness in Il Lavoratore Italiano could also fail to resonate with readers for reasons unrelated to their (more or less strong) sense of regionalism. Indeed, Italy itself, the workers' native land, was not always associated with good memories. In the following excerpt, a reader voiced his outrage at the cost, the inefficiency, and, above all, the conceit of Italian consuls in the U.S.:

\footnotetext{
${ }^{13}$ Ibid., 11 May 1906.

${ }^{14}$ Ibid., 11 May 1906.

${ }^{15}$ Ibid., 26 Jan. 1906.
} 
Whoever has forgotten Italy, whoever is unable to conceive what the Italian government is like, and wishes to know, only has to pay a visit to some Italian consul in order to refresh his memory about the Italian government's capacity to arouse the very feelings which prompted us to leave our families and our customs, and to come to this foreign land.

Chiunque abbia dimenticato l'Italia, chiunque non possa concepire cos'è questo governo italiano e voglia conoscerlo o rinfrescare la sua memoria di tutto quanto è atto ad inspirare i sentimenti che ci indussero, volenti o nolenti, a lasciare la nostra famiglia, le nostre abitudini, per recarsi in questa straniera terra, basta che per una volta si rechi a visitare gli uffici di qualche consolato italiano. ${ }^{16}$

For other readers, Italianness may have been associated with painful feelings of estrangement, especially from their own families, as it was for this miner in Coal City, Illinois, who wrote, "My dear daughter Mary Bracco! I've always done everything I could for you, but you're American and you don't remember your own father. That's why I'd like to remind you that you're the daughter of a Dago father and a Dago mother, as well as many other beautiful things" "Cara mia figlia Mary Bracco! Io ho sempre fatto tutto quello che ho potuto per te, ma tu sei americana e non ti ricordi più di tuo padre. E perciò ti voglio rammentare che sei figlia di madre e padre dagos e tante altre belle cose"). ${ }^{17}$

Needless to say, as Italians were being called—or called themselves— "Dagos," many readers and rank-and-file activists must have had some trouble trying to reconcile the principles of working-class solidarity with their own experiences in the field as ethnic workers. Owing to the segmentation of labour in the mining sector, where a worker's position depended on his ethnic background — and on his regional origin, too, if he was Italian (Vecoli, "Dalle Marche," 287)—resentment would sometimes prevail over solidarity between ethnic groups. For instance, one reader in Illinois complained that Croatians, by far the largest group in his mining camp, did not need to wait for up to six months, as other workers usually did, before they could dig coal on their own account; he concluded, "I had never met

\footnotetext{
${ }^{16}$ Ibid., 22 Dec. 1905.

${ }^{17}$ Ibid., 22 Dec. 1905.
} 
any Croatians before, but now that I have, good riddance!" ("Non avevo mai avvicinato croati, ma ora che li conosco ... alla larga!"). ${ }^{18}$ Another one, in Mercur, Utah, was outraged that, of the 200 Mormons employed in the mine, only one was affiliated with the WFM, and he concluded that "[t]he [199] others live under the yoke of a religion that would excommunicate anyone who dared belong to a union" ("Gli altri sono legati dalla ferrea catena della religione mormonica che scomunicherebbe il membro che osasse appartenere a unioni che si prefigono di educare gli animi e migliorare le sorti della classe lavoratrice"). ${ }^{19}$

This is not to say that ideals of working-class solidarity were absent from readers' contributions to Il Lavoratore Italiano: some referred to miners of all ethnic groups as "our brothers on strike;" 20 others declared, after the arrest of several IWW leaders, that they were "ready to make any sacrifice required to ensure that our brothers Moyer, Haywood, Pettibone, and St. John will be free again" ("pronti a sopportare qualunque sacrificio pur di poter concorrere a ridare la libertà ai nostri fratelli Moyer, Haywood, Pettibone e St. John"). ${ }^{21}$ But for many readers, being Italian meant, first and foremost, being an outcast, not only in American society at large but within the U.S. proletariat as well. One of them viewed, for instance, the Italians' ignorance of English as a handicap in industrial conflicts: "Our major problem is that we can't speak English. The few Italians who know some English are suckers" 22 ("L'inconveniente massimo che pesa su di noi è quello di essere ignari della lingua inglese. I pochi italiani che conoscono l'inglese sono disgraziatamente 'suckers' più del necessario"). He was certainly proven right, as three other readers wrote, in a joint statement, that they had collected 51 signatures on a petition in McAlester, in the Indian Territories (today's Oklahoma), but their union's headquarters in Indianapolis had returned the letter, asking them to rewrite it in English. ${ }^{23}$ Significantly, the petitioners were requesting leave to form an Italian local within their union, a situation that somehow repeated itself during

${ }^{18}$ Il Lavoratore Italiano, 13 July 1906.

${ }^{19}$ Ibid., 24 Aug. 1906.

${ }^{20}$ Ibid., 26 Apr. 1906.

${ }^{21}$ Ibid., 19 Apr. 1906.

22 Ibid., 19 Apr. 1906. The italics are mine and indicate an English word in the original contribution in Italian.

${ }^{23}$ Ibid., 29 June 1906. 
conflicts in the mining camps, as a contributor in Mc Guire, Colorado, described: "At the Consolidated Coal Company, we have no idea if there are any Italians working at the Cuccu Mine, but if there are, we ask them to join us" ("Noi della Co. Coal Co. non sappiamo se nella mina della Cuccu lavorassero italiani, ma, nel caso, li preghiamo di unirsi a noi"). ${ }^{24}$

\section{Italian workers of the world, or the rise of the readers' own version of their imagined community}

In light of Marcella Bencivenni's argument that informal cultural networks offered more opportunities to convert workers to radicalism and recruit new members than union or party meetings did (222), the actual impact among Italian immigrants of such radical newspapers as Il Lavoratore Italiano probably requires further investigation (Bencivenni 222). If the readers' letters and contributions made it possible for us today to hear their voice and, therefore, have a clearer idea of the gap between their immediate concerns and the newspaper's editorial line, they also highlight one of the major functions of Il Lavoratore Italiano and provide some insight into the readers' own version of their imagined community. For Il Lavoratore Italiano was not only the official press organ of a powerful miners' union: the newspaper also provided a precious interactive space to the readers, many of whom were "workers of the world" 25 who belonged to dispersed communities and who, therefore, needed to exchange local information about mining towns across the U.S.—and even beyond—and keep in touch with relatives and friends established in distant mining communities.

Like many other radical newspapers and, especially, union newspapers, Il Lavoratore Italiano relied, across the small mining towns of the West and the Midwest, on a network of collaborators (usually unpaid) who were entrusted with a number of tasks and missions consisting, in particular, of taking care of subscriptions, fundraising, preparing the editors' propaganda tours, passing local information on to the editors, and possibly, too, sending regular written contributions. In its 23 March 1906 issue, Il Lavoratore Italiano directly addressed its correspondents: "To our correspondents. Owing to lack of space, we are obliged to postpone to a later date the publication of many contributions that should

\footnotetext{
${ }^{24}$ Ibid., 2 Feb. 1906.

${ }^{25}$ For the expression and its implications, see Gabaccia and Iacovetta; Gabaccia and Ottanelli.
} 
have appeared in this issue" ("Ai nostri corrispondenti. Per mancanza di spazio siamo costretti di rimandare ad un'altra settimana la pubblicazione di numerose corrispondenze che avrebbero dovuto veder la luce su questo numero"). Because these collaborators were dedicated activists sharing most of the views expressed in the paper's editorial line and, at the same time, were full members of the local mining communities from which they were writing, their contributions were an intricate mix of propaganda and practical information.

Ordinary readers, too, were welcomed and even encouraged to join the discussion, and many sent articles or letters to the editors. Very often, the readers' concerns were practical and personal. Of course, they, too, sometimes used the pages of Il Lavoratore Italiano to voice their anger, express heartfelt ideological views, or spread propaganda, as a reader from Wisconsin did, denouncing religious bigotry in an article entitled "Religious babble and bigoted ignorance" ("Bava Santa e ignoranza di bigotti"), which started in this way:

Encouraged by the appeal that Il Lavoratore Italiano made to all workers, even those with little education, to contribute to the writing of the paper, I'm sending these few lines that I hope will be of some use to those of your regular readers who nonetheless fall under the influence of religious obscurantism.

Incoraggiato dall'appello che fai a tutti i lavoratori - anche se pochissimo istruiti - di collaborare nelle tue colonne, ti mando due parole che spero arrecheranno qualche beneficio a coloro che quantunque ti leggono ogni settimana pur tuttavia si lasciano influenzare dall'oscurantismo religioso. ${ }^{26}$

For many readers, however, Il Lavoratore Italiano seemed, above all, to be a medium through which precious information could be shared about a number of mining towns and areas across the U.S. One of the readers wrote very explicitly that he wanted to tell about his misfortunes in a Colorado camp "so that all readers of $I l$ Lavoratore Italiano who do not have the amazing chance to live in Colorado will be aware [of the situation there]" ("affinchè tutti i lettori del 'Lavoratore' che non hanno l'inestimabile fortuna di vivere nel Colorado sappiano"). ${ }^{27}$

\footnotetext{
${ }^{26}$ Ibid., 2 Feb. 1906.

${ }^{27}$ Ibid., 23 Feb. 1906.
} 
Through the pages of Il Lavoratore Italiano, immigrants exchanged precise and supposedly reliable information about such critical issues as wages, work hours, weather conditions, security in the mines, local unions, workplace conditions, and relations with bosses or with other ethnic groups. For instance, a miner wrote about Mount Olive, Illinois:

The camp is about two miles away from Mount Olive and I think the mine's one of the best in Illinois, in terms of both the amount of work and the amount of salary. But there's a major drawback: we've been working day and night for about a year. We're on day shift one week and on night shift the next.

Il campo dista circa due miglia da Mount Olive e credo sia una delle migliori miniere dell'Illinois, sia per bontà di lavoro che di paga. Ma ... c'è un formidabile ma. Si lavora tutti i giorni e tutte le notti da circa un anno. Lavorano due sciolte. Una settimana si lavora di giorno e l'altra di notte. ${ }^{28}$

Another wrote from Hanna, Wyoming: "I advise all fellow workers to keep away from this camp! There's an evil gang ruling this camp. Most of the residents are Finnish or Swedish. If someone has something nice to say about the Union, he's sure to be thrown out like a dog" ("Prego tutti i compagni di lavoro di non recarsi in questo campo, dove regna una camorra del diavolo. La maggior parte degli abitanti sono finlandesi o svedesi. Se qualcuno si arrischia a buttar fuori una parola in merito all'Unione è sicuro di esser cacciato via come un cane"). ${ }^{29}$

Incorrect or incomplete information, often published in other newspapers, was corrected or completed by contributors who were perfectly aware of the local circumstances because they lived on the premises. ${ }^{30}$ For example, one of them wrote about the construction of a railway line in Washington State:

Very large numbers of workers will be employed on the construction sites. All of the job centers of the towns on the Pacific Coast have

\footnotetext{
${ }^{28}$ Ibid., 13 July 1906.

${ }^{29}$ Ibid., 19 Apr. 1906.

${ }^{30}$ Ibid., 22 June 1906; 13 July 1906.
} 
been asked to hire men and, immediately, as I'm sure you've seen, the scabs and their newspapers have spread the news across the whole county so that the largest possible number of men will come over here and wages will drop. But we can assure you that there are many more men than needed here in the West to do the work.

Nei lavori verranno occupati numerosi operai. Tutte le agenzie [employment offices] delle città della costa del Pacifico hanno ricevuto l'ordine di arruolare uomini e subito - come avete visto - tutta la stampa krumira ha strombazzato ai quattro venti l'annuncio di questi lavori, collo scopo di far aumentare il più possibile le offerte di mano d'opera e diminuire in conseguenza i salari. Noi siamo in grado di assicurare che gli uomini occorrenti alla costruzione di questa ferrovia possono essere forniti ad esuberanza dagli Stati dell'Ovest. ${ }^{31}$

Another reader wrote the following about the coal mines of Thurber, Texas:

In the 'Italo Americano' of New Orleans, we've come across an article, which said, among other stupid things, that Thurber, Texas, is a huge mining camp at 1,000 meters above sea level, where the air is pure and 4,000 miners are employed [...]. There are 1,200 miners in Thurber, not 4,000. The difference is 2,800 ; it's big enough to be noted. The air is pure, but only for those who exploit the miners, not for the miners, who don't have time to enjoy it. In the pits, the air is not pure. The article says the miners' average wages are two dollars for eight hours' work. The truth is many miners don't even manage to make a dollar and a half a day.

Per caso abbiamo letto sul giornale 'L'Italo Americano' di New Orleans un articolo nel quale fra le molte menità si dice che Thurber, Texas è un grandioso campo minerario carbonifero, a mille metri dal livello del mare, con 4,000 minatori e aria balsamica [...]. I minatori di Thurber sono 1,200 e non 4,000: la differenza è di 2,800 e merita di essere rilevata. L'aria è salubre, ma per gli sfruttatori, non pei minatori che non hanno il tempo di goderla. Nel sottosuolo l'aria non è buona.

${ }^{31}$ Ibid., 30 Mar. 1906. 
Il guadagno medio dei minatori sarebbe, secondo l'articolista, non inferiore a 2 dollari per una giornata di otto ore. La realtà dei fatti ci informa invece che molti minatori non arrivano a guadagnarsi un dollaro e cinquanta. ${ }^{32}$

Undoubtedly, this type of information was precious to the readers of Il Lavoratore Italiano. In the first decade of the twentieth century, most Italians settled only very temporarily in the small mining towns of the West and the Midwest. Many were very mobile as they circulated between distinct mining towns and regions where relatives and fellow villagers had settled. For instance, Italian immigrants from just seven small neighbouring towns and villages in the Umbrian Apennines were found to have scattered across, and circulated between, a large number of specific mining towns located in Lorraine and Luxembourg; Pennsylvania's anthracite region; the iron ranges of Minnesota and Michigan's Upper Peninsula; and the coal-mining areas of Illinois and southeastern Kansas (Rinaldetti). Members of such dispersed regional or village communities - to which Donna Gabaccia referred as Italy's many diasporas with their village "homes" and workplace "satellites" (Gabaccia 67) - frequently changed destinations between two successive international migration moves, or travelled on to another mining town or area after arrival.

Therefore, in allowing its readers to exchange precious information on potential destinations, Il Lavoratore Italiano probably facilitated the rise of these dispersed communities, especially given the newspaper's wide circulation among Italian miners in Kansas and beyond. The figure of 10,000 weekly copies boasted by the editors in 1912 may have been overestimated: ${ }^{33}$ N.W. Ayer and Son's American Newspaper Annual and Directory indicated a much more modest weekly circulation of only 2,500 in 1918 (Cartosio, "Italian Workers" 425). Yet, with the exception of a few weeks, Il Lavoratore Italiano benefited from over two decades of uninterrupted publication between 1905 and 1927, an impressive achievement given the difficulties of Italian-language publications in general, and of radical ones in particular. ${ }^{34}$ Above all, Il Lavoratore Italiano probably touched

\footnotetext{
${ }^{32}$ Ibid., 22 June 1906.
}

33 Il Lavoratore Italiano, 20 Sept. 1912.

${ }^{34}$ Produced by militants with little money or experience, radical Italian-language newspapers were almost entirely dependent on financial contributions and, therefore, publication was often short-lived and circulation, limited. It has been pointed out that the aggregate circulation of 
a much larger number of Italians than its circulation figures would suggest, as immigrants sometimes mailed copies to their friends and relatives back home or in other mining towns. Also, as public readings were organized to the benefit of the illiterate in Italian clubs and associations, especially, though not exclusively, in the coal mines of southeastern Kansas, where the newspaper was published. One reader in Russell Gulch, Colorado, wrote about such an experience: "The other night, together with several comrades, we spent the evening as usual, having fraternal conversations, reading our salutary newspaper, and singing socialist hymns" ("L'altra sera, come di solito, eravamo riuniti, in diversi compagni di lavoro, ad una conversazione fraterna, a leggere il nostro salutario periodico ed a cantare inni socialisti”). ${ }^{35}$

Unsurprisingly, Il Lavoratore Italiano reflected the actual circulation patterns of its readers. In a column entitled "Pittsburg and its surroundings" ("Pittsburg e dintorni"), the readers of Il Lavoratore Italiano recounted their daily lives and experiences in an impressive number of small mining towns. These towns were, in reality, much farther away from Pittsburg than the column's title would lead one to believe: contributions came in not only from Kansas but also from Illinois, Michigan, Minnesota, Wisconsin, Iowa, and Indiana in the Midwest; and from Colorado, the Indian Territories, Utah, New Mexico, Arizona, California, and Wyoming in the West. The local American press certainly did not show as much interest in such small and remote localities. If Il Lavoratore Italiano chronicled such a vast, and yet very specific, section of the U.S. territory, it was because these were precisely the small mining towns where the readers had their relatives and friends, where they had sometimes previously sojourned, or where they might consider travelling in the future. In a way, it should come as no surprise that the aforementioned column should be entitled "Pittsburg and its surroundings." Immigrants who had come all the way from Europe and were used to moving about throughout a vast territory spanning two continents, distances between towns were measured primarily according to the place each locality occupied in the immigrants' "mental maps" (Gabaccia and Iacovetta xi), which in turn depended on their previous trajectories and on the awareness they had acquired of the

the 40 titles (radical and non-radical) published in Italian in $1910(548,000)$ was relatively low compared to the circulation of the 23 titles of the Yiddish-language press $(808,000)$. See Vecoli, “The Italian Immigrant Press," 19.

${ }^{35}$ Il Lavoratore Italiano, 13 Apr. 1906. 
locality - through direct experience or through the pages of Il Lavoratore Italiano. Significantly, the newspaper itself had a "history of mobility," as it was first published in Trinidad, Colorado, until its founder, Edoardo Caffaro, was expelled from the state in the aftermath of the 1903-1904 strike, after which publication was resumed in Pittsburg, Kansas, where Caffaro had resettled (Cartosio, "Italian Workers," 429).

Italian immigrants belonging to a dispersed community used Il Lavoratore Italiano also to communicate directly among themselves by writing personal letters or messages in its columns. In one such letter, an Umbrian migrant in the coal fields of Kansas dedicated a short text to the memory of a young relative who had just died in a tragic accident in the iron mines of Michigan: "Dear Leonardo, just as your future started to look brighter, and the prospect of going home to kiss your loved ones made your last days in America delightful, the Grim Reaper came unexpectedly to pull you out of this damned valley" ("Caro Leonardo, ora che l'avvenire ti sorrideva roseo, ora che il miraggio di ritornare in Italia ad abbracciare la tua adorata famiglia ti rendeva lieti questi ultimi giorni di permanenza in America, la falce sterminatrice è venuta a toglierti improvvisamente da questa valle di infamia"). ${ }^{36}$ In another letter, a female migrant in Oklahoma reacted personally, in an open letter to a fellow townsman in Luxembourg, to events concerning her friend's family back home in Umbria, events that happened to already have been discussed in the columns of Il Lavoratore Italiano: "Dear comrade, I have read in 'Il Lavoratore' about the misfortunes of your children in Gualdo Tadino. This was to be expected. But you didn't want to believe it, remember?" ("Caro compagno, ho letto su 'Il Lavoratore' della sventura toccata ai tuoi bambini a Gualdo Tadino, Umbria. C'era da immaginarselo! Ma tu non volevi crederlo, ti rammenti?’). ${ }^{37}$

Very often, when someone was mentioned in a reader's letter or contribution, his first name and family name were given, followed by his region or province of origin in Italy, as was the case, for example, in the account of a fight between two Italian miners, one "Michele Squarcia from the province of Bari" in Apulia and one "Salvatore D'Andrea from the province of Cosenza" in Calabria. ${ }^{38}$ This might come as a surprise in a radical newspaper whose columns and leaders regularly denounced the so-called campanilismo and regionalismo, those two forms

\footnotetext{
${ }^{36}$ Il Lavoratore Italiano, 16 Nov. 1906.

${ }^{37}$ Ibid., 12 Jan. 1912.

${ }^{38}$ Ibid., 19 Apr. 1906.
} 
of very local allegiance (for the native village or region, respectively) that still deeply divided Italians in the early twentieth century. However, this way of presenting people does make sense if one keeps in mind that much of the information in the readers' letters and contributions was not about perfect strangers—as is normally the case in the press-but about individuals whom other readers might know and who should therefore be presented in a way that made identification possible.

\section{Conclusion}

The analysis of the interactions at work within and around Il Lavoratore Italiano - between the newspaper's editors and its readers, with editors of different publications and radicals of different persuasions, and between readers - stresses the overall importance of exchanges between readers themselves, and the role these exchanges at the bottom end of the editorial process actually played in early communities of Italian immigrants who still largely defined themselves in local terms, in spite of their radical sympathies and the editors' agenda.

For ethnic workers confronted with the grim realities of industrial capitalism and racial discrimination in the mining camps of the United States, Il Lavoratore Italiano was undeniably a precious source of inspiration and education, as the radical newspaper shed some light on their experiences, giving a sense of purpose to their lives. But for labour migrants whose personal networks of relatives and friends were dispersed in a significant number of mining towns across the U.S., Il Lavoratore Italiano was, above all, a very efficient means to reinforce their networ$\mathrm{ks}$ and reduce, in the process, the distances between mining communities, as these "Italian workers of the world" would commonly use the newspaper's pages to keep in touch with faraway communities and share the information they needed to circulate between them.

Finally, judging from their letters and contributions to Il Lavoratore Italiano, localism seemed to have been essential to the readers' own understanding of their complex identities-with their inevitable mix of ethnic and class elements. In its social and industrial dimension, localism equalled the concrete realities of the mining town; the companies and bosses; the work conditions and relations in the mines-all of which made at least as much sense to the readers as the abstract notions or ideals of class-consciousness and the solidarity of the international proletariat. In its geographical and political dimension, localism meant that readers identified less with any nationalist, internationalist, or transnational abstraction 
than with their own "territory," a notion that Paul-André Rosental defines as all the localities to which migrants are linked through migration, personal contacts, or exchanges, and that mirrors both the past-as migrants inherit their space references from past trajectories (Rosental 50-51) —and the future-as their territory also includes all the job markets potentially accessible to them (Audenino 257-261). Paradoxically, mobility, one of the most salient traits of the Italian workers' multi-layered identities, to this day remains one of the least documented aspects of life in the early Italian immigrant communities in the United States.

Université Paris 8

\section{Works Cited}

Audenino, Patrizia. Un mestiere per partire: Tradizione migratoria, lavoro e comunità in una vallata alpina. Milan: FrancoAngeli, 1900.

Bencivenni, Marcella. Italian Immigrant Radical Culture: The Idealism of the Sovversivi in the United States, 1890-1940. New York: New York UP, 2011.

Bezza, Bruno (ed.). Gli italiani fuori d'Italia: gli emigrati italiani nei movimenti operai dei paesi di adozione. Milan: FrancoAngeli, 1983.

Cannistraro, Philip V., and Gerald Meyer (eds.). The Lost World of Italian American Radicalism. Westport: Praeger, 2003.

Cartosio, Bruno. "Italian Workers and Their Press in the US, 1900-1920." In The Press of Labor Migrants in Europe and America, 1880s to 1930s. Ed. Dirk Hoerder and Christiane Harzig. Bremen: Labor Newspaper Preservation Projekt, 1985. 423-442.

. "Gli emigrati italiani e l'Industrial Workers of the World." In Gli italiani fuori d'Italia: gli emigrati italiani nei movimenti operai dei paesi d'adozione, 1880-1940. Ed. Bruno Bezza. Milan: FrancoAngeli, 1983. 359-395.

Deschamps, Bénédicte. "La scoperta dell'America narrata dai giornali italo-americani." In Comunicare il passato: Cinema, giornali e libri di testo nella narrazione storica. Ed. Simone Cinotto and Marco Mariano. Turin: L'Harmattan Italia, 2004. 409-438. 
"Lépreuve / les preuves de la loyauté : La presse italo-américaine face à la citoyenneté, 1910-1935." Revue Française d'Etudes Américaines 75 (1998): 47-60.

Deschamps, Bénédicte, and Stefano Luconi. "The Publisher of the Foreign-Language Press as an Ethnic Leader? The Case of James V. Donnaruma and Boston's Italian-American Community in the Interwar Years." Historical Journal of Massachusetts 30.2 (2002): 126-143.

Gabaccia, Donna R. Italy's Many Diasporas. Seattle: U of Washington P, 2000.

Gabaccia, Donna R., and Franca Iacovetta (eds.). Women, Gender, and Transnational Lives: Italian Workers of the World. Toronto: U of Toronto P, 2002.

Gabaccia, Donna R., and Fraser M. Ottanelli (eds.). Italian Workers of the World: Labor Migration and the Formation of Multiethnic States. Urbana: U of Illinois P, 2001.

Il Lavoratore Italiano [Pittsburg, KS]. Microfilm. Periodicals, Italian-American Collection, Immigration History Research Center, University of Minnesota. Jaroszyńska-Kirchmann, Anna D. “'Everybody Writes': Readers and Editors and Their Interactions in the Polish-Language Press, 1922-1969." Journal of American Ethnic History 33.1 (2013): 35-69.

Lacorne, Denis. La crise de l'identité américaine. Paris: Fayard, 1997.

Luconi, Stefano. "Anti-Americanism in the Italian-Language Press in the United States in the Interwar Years." In L'antiaméricanisme / Anti-Americanism at Home and Abroad. Conference Proceedings, March 26-27, 1999, Aix-enProvence. Ed. Sylvie Mathé. Aix-en-Provence: Publications de l'Université de Provence, 2000. 33-48.

Nelli, Humbert S. "Chicago's Italian-Language Press and World War I." In Studies in Italian American Social History: Essays in Honor of Leonard Covello. Ed. Francesco Cordasco. Totowa, New Jersey: Rowan and Littlefield, 1975. 66-80.

Notarianni, Philip F. "Italian Involvement in the 1903-04 Coal Miners' Strike in Southern Colorado and Utah." In Pane e lavoro: The Italian American Working Class. Ed. George E. Pozzetta. Toronto: Multicultural History Society of Ontario, 1980. 45-65.

Pernicone, Nunzio. Italian Anarchism, 1864-1892. Edinburgh: AK Press, 2009.

Prencipe, Lorenzo. "Stampa 'in e di' emigrazione: Informazione nell'ottica della 'formazione'." Studi Emigrazione 46.175 (2009): 515-524. 
Rinaldetti, Thierry. "Italian Migrants in the Atlantic Economies: From the Circulation of the Birds of Passage to the Rise of a Dispersed Community." Journal of American Ethnic History 34.1 (2014): 5-30.

Rosental, Paul-André. Les sentiers invisibles: Espaces, familles et migrations dans la France du dix-neuvième siècle. Paris: Ed. de l'Ecole des Hautes Etudes en Sciences Sociales, 1999.

Topp, Michael Miller. Those Without a Country: The Political Culture of Italian American Syndicalists. Minneapolis: U of Minnesota P, 2001.

Vecoli, Rudolph J. "Dalle Marche e dall'Umbria alle miniere del Lago Superiore." In Le Marche fuori dalle Marche: Migrazioni interne ed emigrazione all'estero tra XVIII e XX secolo. Conference Proceedings, March 20-22, 1997, Fabriano. Ed. Ercole Sori. Vol. 3. Senigallia: Libreria Sapere Nuovo, 1998. 677-694. . "The Italian Immigrant Press and the Construction of Social Reality, 1850-1920." In Print Culture in a Diverse America. Ed. James P. Danky and Wayne A. Wiegand. Urbana: U of Illinois P, 1998. 17-33.

Vezzosi, Elisabetta. Il socialismo indifferente: Immigrati italiani e Socialist Party negli Stati Uniti del primo Novecento. Rome: Ed. Lavoro, 1991.

. "Class, Ethnicity, and Acculturation in Il Proletario." In The Press of Labor Migrants in Europe and America, 1880s to 1930s. Ed. Dirk Hoerder and Christiane Harzig. Bremen: Labor Newspaper Preservation Projekt, 1985. 443-458. 
